Kjell Atle Halvorsen

Program for lcererutdanning

Norges teknisk-naturvitenskapelige universitet

Email:kjell.halvorsen@svt.ntnu.no

Siw Skrøvset

Institutt for lcererutdanning og pedagogikk

Universitetet $i$ Tromsø, Norges arktiske universitet

Eirik Johannes Irgens

Program for lcererutdanning

Norges teknisk-naturvitenskapelige universitet

\title{
Learning for Leadership
}

\begin{abstract}
How do participants in the National Leadership Education for School Principals conceptualize school leadership, and how has their participation in the program affected them as leaders? These are the questions analyzed in this article, based on data from a student cohort comprising 63 students. We have analyzed one of their portfolio texts and their responses to an electronic open-question survey. Findings are discussed in the light of school leadership theories, Mintzberg's (2009) triangular theory of leadership and a graded concept of theory (Ertsås \& Irgens, 2016).

Participants conceptualize school leadership as a complex practice exercised by knowledgeable role models, whose leadership is focused and transparent, rooted in common core values, sound working relations, bent on improving student learning. A variety of elements in the program have contributed to developing participant concepts of leadership. The fusion of strong theory and practical experience seems to have played a predominant role. Our findings contrast criticisms of management education programs in the international literature. Our analyses are based on participant self-reports, which restricts the scope of our conclusions. There is a need for further research on the links between leaders' espoused conceptualizations of leadership and their actual leadership practice.
\end{abstract}

Keywords: school leadership, leadership education, National leadership education for school leaders

\section{Sammendrag}

Hvordan konseptualiserer deltakere $i$ den norske rektorutdanningen skoleledelse, og hvordan har deres deltakelse i programmet påvirket dem som ledere? Disse spørsmålene drøfter vi i denne artikkelen på grunnlag av data fra 
en gruppe på 63 studenter. Vi har analysert en av deres mappetekster og svar på et elektronisk spørreskjema med åpne spørsmål. Funnene drøftes i lys av teori om skoleledelse, Mintzbergs (2009) triangulcre ledelsesteori og et gradert teorikonsept (Ertsås \& Irgens, 2016).

Deltakerne konseptualiserer skoleledelse som en kompleks praksis utøvd av kunnskapsrike rollemodeller, hvis lederskap er fokusert og transparent og forankret i felles kjerneverdier, med gode relasjoner mellom kolleger og fokus på elevenes lcering. Deltakerne påpeker at ulike elementer i rektorutdanningen har påvirket den måten de utøver ledelse på. Kombinasjonen av sterk teori og praktiske øvinger synes å ha vcrt viktig. Funnene våre står $i$ kontrast til den kritikken som har vert rettet mot utdanning av ledere internasjonalt. Våre analyser bygger på deltakernes selvrapportering. Dette setter grenser for hvilke konklusjoner vi kan trekke. Det er behov for mer forskning på forbindelsen mellom skolelederes uttrykte handlingsteori og den ledelsen de praktiserer.

Nøkkelord: skoleledelse, lederutdanning, rektorutdanningen

\section{Introduction}

The quality of school leadership has significant effects on the quality of schools, and the quality of school leadership can be enhanced through education. These are two core assumptions behind the National Leadership Education for School Principals in Norway (St.meld. nr. 31, 2007-2008). The program, comprising a 30 -credit continuing education course on master degree level, was launched in 2009 by the Norwegian Directorate for Education to improve the quality of education in Norwegian schools. This article aims to investigate how a cohort of 63 school leaders conceptualize school leadership and the impact of their participation in the program. The research question guiding our study is twofold: How do school leaders who have participated in the National Leadership Education for School Principals conceptualize school leadership, and what are the effects of their participation on their leadership?

A sketch of central program elements is followed by a brief alignment of the National Leadership Education for School Principals with international trends in leadership education. Our study is set off against a background of criticism of management education, and our analytical tools are predominantly derived from Mintzberg's triangular theory of leadership and a graded concept of theory. We then address our research questions by presenting our analysis of 63 participant papers and participant responses to an open question survey. After discussing our findings in the light of the theory presented we point to a central challenge for future research. 


\section{Course design}

The course attended by our informants covered the following four main themes: school organization, leading for learning, school in society and the role of the head teacher. The ambition was to facilitate school leaders' professional, intellectual and personal development by applying relevant theory to their workplace experiences. The Jung Type Indicator (JTI) was used as a platform for enhanced self-insight and understanding of preferential differences among fellow students and colleagues.

During three semesters, school leaders met for seven three-day on-campus seminars with lectures, plenary and group discussions, individual and group supervision, and skills based exercises. They were organized in permanent groups of 8-10 students. One faculty member was assigned as supervisor to each group. These groups became havens for face-to-face exchanges of peer insights and experiences as well as training of leadership skills.

Between seminars the participants worked on written assignments in which they were instructed to reflect on workplace challenges, analyzing their own leadership issues in theoretical perspectives dealt with in the course. Feedback on preliminary drafts from group members and staff supported the writing process and provided participants with insights into a variety of leadership issues.

\section{Theoretical conceptualizations of school leadership}

According to Mordal (2014), recent Norwegian educational policies assume that good leadership in schools communicates clear targets and expectations, develops a culture for learning in the workplace and keeps administrative routines in good order. Good leadership is, however, difficult to define since it is highly contextual. Mordal points to distributed leadership, instructional leadership, transformational leadership, and collaborative leadership as the most prevalent in the literature. We shall limit ourselves to rather brief characterizations of the first three. Theories on distributed leadership (Spillane, 2006; Gronn, 2002) focus on leadership as a product of interactions between formal and informal leaders, disentangling leadership from the one, heroic leader. Instructional leadership theories emphasize the significance of leadership close to the classroom, facilitating activities that support learning (Hallinger, 2003; Robinson, 2011). Thus, instructional leadership requires a strong, professional knowledge base on teaching and learning. Transformational leadership is often understood as inspirational leadership, emphasizing the leader as a role model who motivates, inspires and challenges her colleagues with high expectations, creativity and personal support (Bass, 1999). 
When investigating how a Norwegian school leader frames her own role, Møller (2009) found tensions between distributed and heroic leadership, between understanding leadership as primarily evolving from democratic interactions between fellow employees and leadership as residing primarily with the one, formal leader. Møller (2011) points out that the school leader's ability to utilize the action room she has earned by force of her position is closely linked to the professional recognition she is granted by her superiors, her peers, and other stakeholders.

Like Mintzberg (2009), Møller points out that school leaders' knowledge production is a bi-product of their practice. They primarily derive their perceptions of themselves as professionals from collaboration with colleagues, previous work experiences, and working closely with students-not from formal leadership education (Møller, 2011).

Møller's findings are interesting in the light of international criticism of management education voiced by e.g. Czarniawska (2003), Ghoshal (2005), and Mintzberg (2004). Although their criticism is primarily aimed at the American MBA tradition, it has relevance for school leadership, which according to Bush (2007) should be studied in the light of insights derived from generic research on leadership. Czarniawska (2003) and Ghoshal (2005) have criticized management education for spreading instrumentalist ideas of control and masculine myths of mastery. Many management education programs teach "overwhelmingly causal or functional" management theories that destroy good management practices (Ghoshal, 2005, p. 78).

In spite of the significance of context, the export of American management ideas to Europe has been strong (Easterby-Smith, Thorp, \& Lowe, 1991). "Management" courses, technical and instrumental in their approach, spread in the university business schools in the wake of modern industry (Irgens, 2016). These courses were vehicles for the export of ideologies that often collided with national values embedded in management theory and practice (Hofstede, 1993).

Contrasting the trends outlined above, the program attended by our informants focused on core school tasks. It was value based and oriented toward developing participants' competence for school development (cp. Huber, 2004), emphasizing the link between theory and practice (Bush \& Glover, 2003; Lumby, Walker, Bryant, Bush, \& Björk, 2009). This was accomplished by allowing time for reflection, individually and in groups, by arranging for learning activities supported by the theoretical framework, and by facilitating experience based learning through working with cases (Lysø, Stensaker, Aamodt, \& Mjøen, 2011). Thus, the program reflected fundamental values embedded in the Nordic tradition such as democracy, dialogue and respect for the individual. This tradition highlights equality and consensus, solidarity and the involvement of unions and employees, facilitating coordination, communication and dialogue (Klemsdal, 2009; Lægreid, Nordø, \& Rykkja, 2013; Schramm-Nielsen, Lawrence, \& Sivesind, 2004). In the Nordic tradition, 
teachers are treated as co-workers rather than followers (Irgens \& Ness, 2007; Irgens, 2016).

Furthermore, the program was inspired by Mintzberg's conceptions of management as a practice constituted by the concepts of art, craft and science. Science is informed by theory and research, the stuff that universities are steeped in. Art is associated with intuitive visioning and imagining. Craft involves leadership actions, the wide variety of things leaders actually do, and is according to Mintzberg primarily learned from experience. Good managing practice consists of a blend: "Put together a good deal of craft with the right touch of art alongside some use of science, and you end up with a job that is above all a practice" (Mintzberg, 2009, p.10).

\section{A graded theory concept}

The approaches to leadership knowledge development outlined so far, are apparently rooted in a dichotomous understanding of theory and practice, which is inadequate if we aim to understand how theory can be used to improve practice. In accordance with Ertsås and Irgens (2016), we call for a processual and graded understanding of theory. Building on Weniger (1953) and Kvernbekk (2005), they differentiate between theories of first, second and third degree, abbreviated T1, T2 and T3. T1 is the theory embedded in practice, equivalent to Argyris and Schön's (1978) theory-in-use. It is a context-related, non-articulated theory that can be identified through observations of what a practitioner actually does. T3 is generic, systematically articulated, strong theory found in research papers. It can be applied to analyze practice as well as other theories. T2 is the articulated theory a practitioner would use to describe his practice (Ertsås \& Irgens, 2016). It takes conscious effort to develop an articulated theory (T2) that is realistic in the sense that it is close to the practitioner's theory-in-use (T1). A strong divergence between T1 and T2 indicates that the practitioner does not have a realistic conception of his practice.

A proficiency developed primarily through experience, will inevitably be near-sighted. Without context independent knowledge and meta-perspectives from outside, unfortunate practices may survive in the shadows of institutionalized, "self-evident truths” (Ertsås \& Irgens, 2016).

We face two potential pitfalls in the process of improving practice. The "tyranny of experience" (Weniger, 1953) may foster near-sighted leadership because it is primarily grounded in the practitioner's own experience and lacks the theoretical meta-perspectives represented by stronger theories (T3). The "tyranny of theory", the uncritical use of stronger theories (T3), may indicate a failure to differentiate between relevant and irrelevant theories combined with an inability to translate generic theories into local practice. 
Professional practice must be legitimized pragmatically as well as theoretically, and needs to be informed by strong theory (T3) as well as experience (T1) (Ertsås \& Irgens, 2016). The development of good practice depends on the capacity to theorize professionally, understood as "a process of informed reflection where an individual or a group reflects on, formulates, analyses, gives rationales for and develops practice informed by theory of different degrees” (Ertsås \& Irgens, 2016, p. 1). Where Minztberg gives priority to practice, Ertsås and Irgens (2016) claim that both stronger theories (T3) and experience (T1) are needed to develop good leaders.

\section{Method}

Our unit of analysis is a student cohort of 63 school leaders, and our analyses are based on material collected from this group. To investigate how they conceptualize school leadership, we analyzed one of the four texts submitted for final portfolio assessment. In this text participants were instructed to outline the context for their leadership, the values that underpin it and the challenges they face in the light of theories central to the leadership program. They were encouraged to be specific about any consequences their participation in the program might have had on their leadership profiles. Approximately 630 pages of student text were analyzed inductively, building on grounded theory (Bowen, 2006). Through a process of open, axial and selective coding we collected representative statements illuminating the informants' concepts of school leadership and organized them in five major categories using the constant comparative method of analysis (Corbin \& Strauss, 2008). The following main categories were constructed:

- Complexities of leadership

- Leadership as relational

- Leading for learning

- Developing school culture

- Leading change

The main categories were organized in a mind map with key concepts representing the subcategories supporting them (Figure 1). This procedure may be problematized from a methodological point of view-for two reasons. First, the amount of text to be analyzed may challenge the transparency of the analysis. Secondly, the authors, who conducted the analysis, were providers of the program that the informants had completed and might—subconsciously-be influenced by their prior understanding of matters to be investigated. Both points challenge the validity of the analysis and put the integrity of the authors to the test. However, none of the authors had vested interests in the outcome of the 
analysis, and — we would argue - the researchers' familiarity with the field to be investigated overshadows the methodological drawbacks.

Furthermore, we have analyzed participant responses to an electronic survey carried out at the termination of the program. Participants were asked to answer the following open questions:

1. How has your participation in the National Leadership Education for School Principals affected your development as a leader?

2. What elements in the National Leadership Education for School Principals have been particularly useful to you as a leader?

3. How has your work with the portfolio texts affected your development as a leader?

4. Has your participation in the National Leadership Education for School Principals caused changes in your own workplace?

5. If your answer to question 4 was positive: What changes in your workplace has your participation in the leadership program contributed to?

6. What measures are you planning (in your workplace) as a result of your participation in the leadership program?

51 out of 63 participants responded to the questionnaire, yielding a response rate of 81. The survey responses were analyzed in the same way as the student papers. The categories developed were used to construct tables 1-6.

\section{Concepts of school leadership}

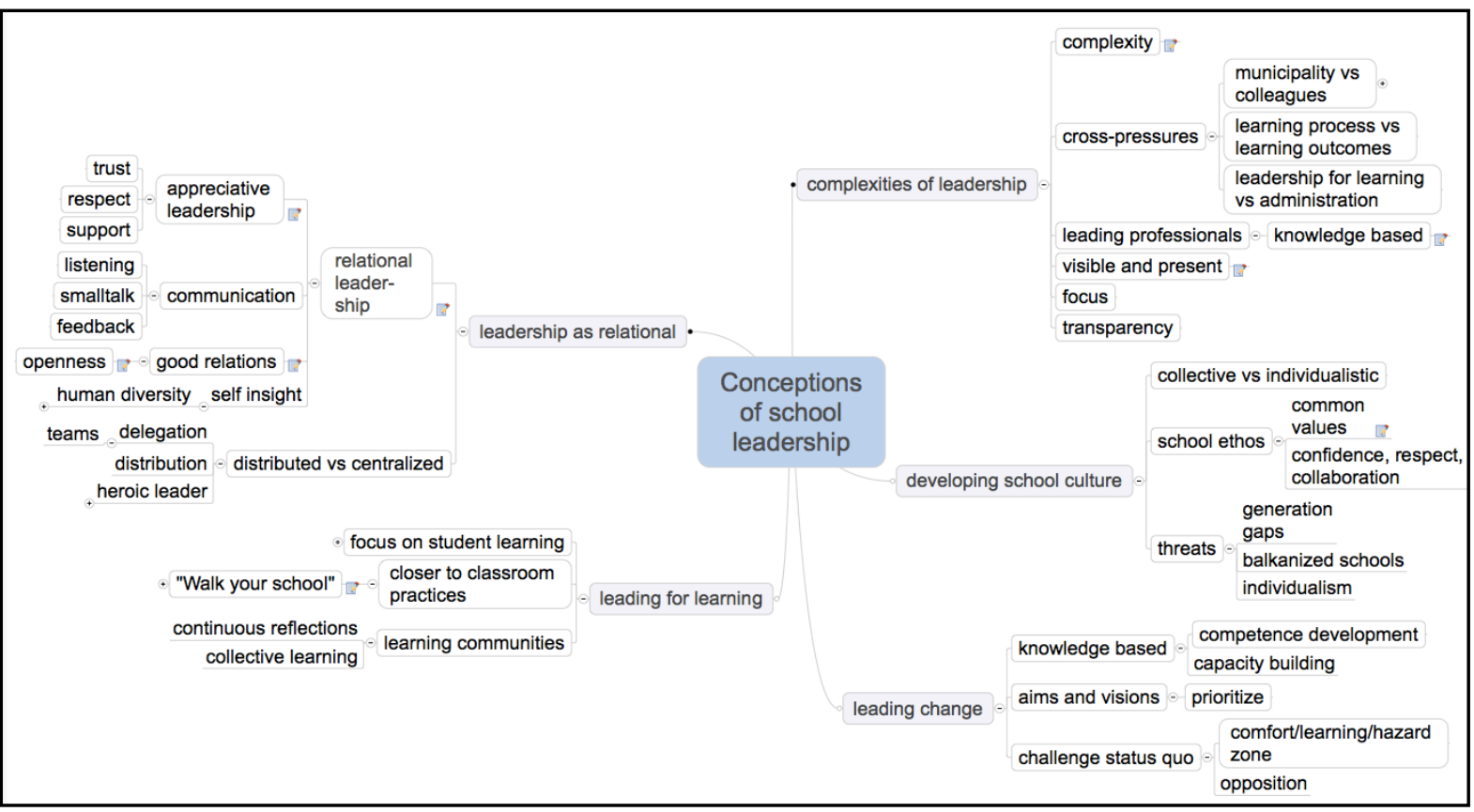

Figure 1. The cohort's collective conceptualization of school leadership 
The mind map in figure 1 renders a representation of the cohort's collective conceptualization of school leadership. It illustrates how the five main categories (complexities of leadership, leadership as relational, leading for learning, developing school culture, and leading change) developed in our analysis of the portfolio texts, are supported by sub-categories.

In the following we summarize the findings rendered in Figure 1 and illustrate main points with representative quotes from student texts.

\section{Complexities of leadership}

School leadership is understood as complex practice, exercised in tensions between contradictory expectations of municipality and colleagues. Conflicting priorities between administration and pedagogy require a knowledge-based leadership focused on student learning. Visible and transparent leadership is required. One of the students describes the complexity like this:

The school head has a highly exposed position, which requires a clear head and a strong back. You face a variety of dilemmas that must be tackled professionally. Demands from (administrative) levels above are many and distinct. Expectations from parents and teachers have escalated in recent years. You need insights in leadership theory, relational competence, law, pedagogy, conflict handling etc.

\section{Relational leadership}

Leadership is seen as a relational practice grounded in self-insight and recognition of human diversity. Ideally, the leader is a role model, epitomizing the core values of the school. She supports colleagues by meeting them with trust and respect. Her appreciative leadership is carried out with small talk and frequent feedback. Aware of her own limitations she recognizes the necessity to delegate and distribute leadership tasks. One of our participants underscores the importance of good relations like this:

The leaders I have looked up to have all maintained good relations to their personnel, not necessarily like friends, but professionally. They have been quite distinct in the execution of their leadership, responsive, supportive, just, and respectful in their encounters with students and collaborators.

\section{Leading for learning}

The school leader is aware that what she can do to promote student learning, is primarily done through the teachers. Her leadership is carried out close to the classroom, with a strong focus on measures that impact student learning positively. She takes advantage of "Walk your school" and similar programs to "create convenient disturbances in teachers' practices to make them reflect on their practices and improve them".

Recognizing that learning is the school's core activity, she takes measures to develop her school into a learning community for teachers as well as students, facilitating continuous, collective learning processes among her colleagues. 
One of our participants described his prime objective—and challenge-like this:

My prime objective as a leader is to contribute to the development of a good and safe learning environment for the students. It is for the students I want to develop a good school. As a leader I must do this indirectly. Consequently I must involve myself with the work and learning of the teachers.

\section{Developing school culture}

Development is closely linked to and dependent upon learning. To achieve her goals of improving student learning she heralds the development of a school culture characterized by common core values epitomized in a shared school ethos and fostered in a collective culture bent on continuous learning through practice and reflection:

It has become clear to me that the school head must meet the complexities of her role with fundamental values and attitudes that characterize the school she leads. The school head is primarily a builder of culture, a guide, a facilitator, and an instigator.

\section{Leading change}

It is the obligation of the leader to define needs for improvement, to prioritize between them, define aims and set the direction for development. Her most significant challenges materialize when leading development projects. When status quo is no longer good enough and independent professionals with long histories of workplace autonomy are forced out of their comfort zones, opposition arises and must be handled. Challenges related to leading change processes are emphasized by a considerable number of our participants. These sentiments are representative:

Our school has always "wanted" change. We have a solid tribe of teachers who really want development. Our challenge has been the small tribe of people who have been positive in public and negative in the back room. When school leaders do not get involved, negative attitudes flourish, too many lag behind, resistance increases and we fail to get the processes that the majority really want. We need leaders with clear aims and visions.

\section{Impacts of the National Leadership Education on perceptions of leadership}

Based on their categorized responses to the questionnaire, we analyze the participants' perceptions of impacts of the program on their leadership. These findings are rendered in tables 1-6. The Responses categorized column renders the main categories developed in the qualitative analyses of the open survey 
questions. In tables 2-6 sub-categories substantiating the main categories are included for added transparency.

In open questions, students are not given leads like they are in closed questions. When $55 \%$ of our respondents confirm that they have become more confident leaders, the implication is not that the remaining $45 \%$ have not become more confident leaders. A closed questionnaire, attracting attention to specific response alternatives, would probably have yielded different results. On the other hand, when asked about outcomes immediately after the termination of a training program, participants may exaggerate positive factors to legitimate the time and energy put into it.

\section{Impact of leadership program on leadership practice}

Table 1 Program effects on leadership as perceived by participants

\begin{tabular}{|llc|}
\hline $\begin{array}{l}\text { 1. How has your participation in the National Leadership Education for School Principals } \\
\text { affected your development as a leader? }\end{array}$ & $\begin{array}{l}\text { Responses } \\
\text { (n=51) }\end{array}$ & \%o of n \\
\hline Responses categorized & 32 & 63 \\
\hline I am familiar with relevant and useful theory and research & 28 & 55 \\
\hline I am a more confident leader & 28 & 55 \\
\hline I have enhanced insight in the role of the school leader & 27 & 53 \\
\hline It has had a significant impact on my leadership & 27 & 53 \\
\hline It has strengthened my leadership in developing a culture for learning & 20 & 39 \\
\hline I have better self-insight and understanding of human diversity & 16 & 31 \\
\hline I am a more confident leader of change and development projects & 14 & 27 \\
\hline I have acquired useful leadership tools & & \\
\hline
\end{tabular}

Table 1 shows that a majority of the school leaders find that their leadership has been significantly impacted. Notably, 55\% claim to have become more confident leaders with a better understanding of their role. A typical statement from one of the participant texts illustrates this point:

I have become more confident in my role, more self-reliant and more conscious, and I communicate better with the leadership team. We have the same optics, as Irgens said in his first lecture.

The "optics" refers to the "relevant theory and research" which a majority of the respondents highlight as a key factor influencing their development as leaders. "Optics" was introduced as a metaphor for theory in the program. It was used by the teachers to illustrate how models and theories present powerful perspectives that help us analyze and improve practice.

Furthermore, it is worth noticing that 53\% maintain that their leadership in developing a culture for learning has been strengthened, which may indicate that participants have moved their leadership closer to classroom activities. 


\section{Useful elements in the program}

Table 2 Useful elements in the program

\begin{tabular}{|c|c|c|}
\hline \multicolumn{3}{|c|}{$\begin{array}{l}\text { 2. What elements in the National Leadership Education for School Principals have been } \\
\text { particularly useful to you as a leader? }\end{array}$} \\
\hline Responses categorized & $\begin{array}{l}\text { Responses } \\
(\mathbf{n}=51)\end{array}$ & $\%$ of $n$ \\
\hline $\begin{array}{l}\text { Knowledge development } \\
\text { Exposure to relevant theory in lectures and literature }\end{array}$ & 35 & 69 \\
\hline $\begin{array}{l}\text { Reflections with fellow students and faculty } \\
\text { Group discussions and reflections, sharing experiences }\end{array}$ & 22 & 43 \\
\hline $\begin{array}{l}\text { Networking } \\
\text { Develop networks and friendships with colleagues }\end{array}$ & 18 & 35 \\
\hline $\begin{array}{l}\text { Relationship building } \\
\text { Building relations (e.g., through appreciative leadership), developing a } \\
\text { common language }\end{array}$ & 18 & 35 \\
\hline $\begin{array}{l}\text { Access to leadership tools } \\
\text { Operationalizing theory, translating theory into actionable knowledge }\end{array}$ & 14 & 27 \\
\hline
\end{tabular}

Tables 1 and 2 show that a majority, 63\% and 69\% respectively, point to the usefulness of relevant theory in text and lectures. Theory is considered to be relevant and useful to the development of their leadership practices. One of our participants reflects on the development of her "toolbox", a metaphor for operationalized theory, like this:

I did have a "toolbox" when I started my studies, but it was lean and entirely based on my own experiences and some of my colleagues. Through lectures and theory you have filled my toolbox with exciting methods that I try out little by little.

The building of this knowledge base was also facilitated through individual and group activities. Three of the categories in table 2 all highlight collaborative scenarios, learning together with and from others, viz. Reflections with fellow students and faculty, Networking, Relationship building. These categories include interactions with fellow students and faculty in face-to face plenary and group exchanges, student and faculty feedback on written assignments, and discussions with colleagues in the workplace. They all facilitated reflections fusing practical experiences and new theory.

Table 3 testifies to the significance of writing in knowledge construction. Students wrote four texts for portfolio assessment, where they were advised to reflect on workplace experiences and challenges in the light of relevant strong theory (T3). In table 3, 55\% pointed out that working with portfolio texts has supported knowledge building, causing deeper theoretical insights and a more profound understanding of the theory and its significance. 
Table 3 Effects of working with portfolio texts on development as leader

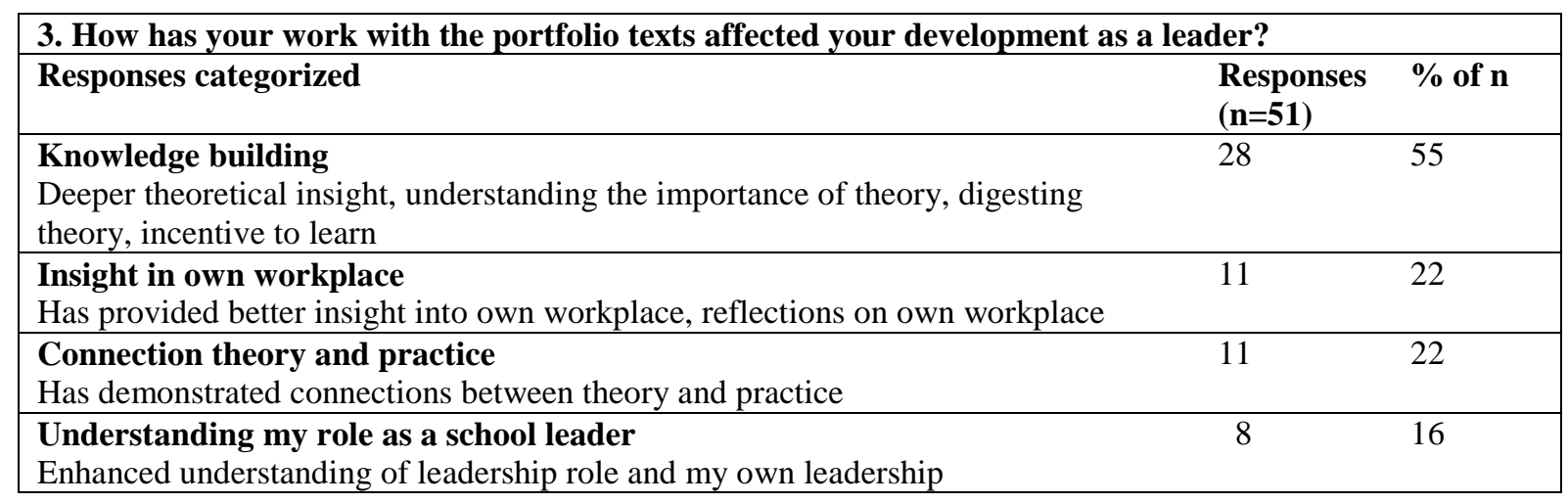

\section{Changes in the workplace}

Table 4 Changes in own workplace caused by participation in the National Leadership Education for School Principals

\begin{tabular}{|llll|}
\hline $\begin{array}{l}\text { 4. Has your participation in the National Leadership Education for } \\
\text { School Principals caused changes in your own workplace? }\end{array}$ & yes & no & \% yes (n=51) \\
\cline { 2 - 4 } & 50 & 1 & 98 \\
\hline
\end{tabular}

Table 5 Changes in own workplace

\begin{tabular}{|c|c|c|}
\hline \multicolumn{3}{|c|}{$\begin{array}{l}\text { 5. If your answer to question } 4 \text { was positive: What changes in your workplace has your participation in } \\
\text { the school leadership program contributed to? }\end{array}$} \\
\hline Responses categorized & $\begin{array}{l}\text { Responses } \\
(n=50)\end{array}$ & $\%$ of n \\
\hline $\begin{array}{l}\text { Leadership profile } \\
\text { More transparent, focused and confident leadership, more feedback, more } \\
\text { appreciative leadership }\end{array}$ & 20 & 40 \\
\hline $\begin{array}{l}\text { Enhanced collective practices } \\
\text { Better meetings, better use of collective time, more collective practice, building } \\
\text { relations, school ethos }\end{array}$ & 17 & 34 \\
\hline $\begin{array}{l}\text { Instructional leadership } \\
\text { Leading closer to classroom practices and student learning }\end{array}$ & 14 & 28 \\
\hline $\begin{array}{l}\text { Enhanced use of theory and reflection } \\
\text { More theory based practice, more reflection }\end{array}$ & 12 & 24 \\
\hline
\end{tabular}

According to table 4, participants are all but unanimous (98\%) that their participation in the program has caused changes in their workplaces. The picture emerging from table 5 is corroborated by the student papers, which contain a plethora of passages describing effects on leadership practice caused by fusions of established insights (T1, T2) with strong theory (T3):

In this paper I have focused on myself as a more confident and transparent leader and I believe that this has affected my leadership. My confidence is rooted in appreciative leadership. I have developed a more transparent leadership through enhanced selfinsight and understanding of the school culture. 
In their own minds many participants have become more confident leaders with better self-insight and understanding of human diversity and a stronger focus on developing the school's learning culture. One of the students described her transformation from administration to leadership for learning like this:

When I started the program I used to be the one who kept running around all day ... doing all the things nobody else did. Administrative duties kept piling up. There was no end to them, and no chance of finishing them. During the course something happened. My focus turned from administration to instructional leadership.

It may be presumptuous to expect students to implement workplace changes while participating in the program. We therefore asked about planned actions. The results are summed up in table 6. A majority of the participants are planning to distribute administrative chores and move their leadership closer to the school's core, classroom activities. These ambitions are supported by measures to develop the school's culture for collective learning.

Table 6 Planned changes in own workplace

\begin{tabular}{|c|c|c|}
\hline \multicolumn{3}{|c|}{$\begin{array}{l}\text { 6. What measures are you planning (in your workplace) as a result of your participation in the } \\
\text { leadership program? }\end{array}$} \\
\hline Responses categorized & $\begin{array}{l}\text { Responses } \\
(\mathbf{n}=51)\end{array}$ & $\%$ of $n$ \\
\hline $\begin{array}{l}\text { Strengthen instructional leadership } \\
\text { Develop culture for learning for students and teachers, reduce time spent on } \\
\text { administrative functions, focus on teaching and student learning, walk your school }\end{array}$ & 26 & 51 \\
\hline $\begin{array}{l}\text { Improve school organization } \\
\text { Improve organization structures, plans, more systems thinking }\end{array}$ & 15 & 29 \\
\hline $\begin{array}{l}\text { Develop role as school leader } \\
\text { Focus, distributed leadership, school-municipality relations }\end{array}$ & 11 & 22 \\
\hline $\begin{array}{l}\text { Develop evidence based leadership } \\
\text { More evidence based school development, evaluations, data driven development, } \\
\text { school based assessment }\end{array}$ & 5 & 10 \\
\hline
\end{tabular}

\section{Discussion}

We first discuss our participants' conceptualizations of school leadership in the light of theories on leadership and leadership competence building. These conceptualizations may have many sources. Participation in the National Leadership Education for School Principals is probably one of them. Secondly, we discuss how school leaders who have participated in this program perceive effects of this participation on their own leadership.

In our discussion, Mintzberg's (2004) triangular conception of leadership as a blend of art, craft and science, and a graded concept of theory (Ertsås \& Irgens, 2016) are our main analytical tools. We have chosen to use Mintzberg's model of leadership because it is a convenient frame for understanding the complexities of leadership. Furthermore, it opens up to a more flexible under- 
standing of the relationship between theory and practice in leadership education. Thus it aligns well with the graded concept of theory, which we use because it replaces the dichotomy between theory and practice with an understanding of how theory can be used to improve practice.

Our study is based on the participants' self-reports in portfolio papers and questionnaire responses. These reports represent their articulated theory, their T2 (Ertsås \& Irgens, 2016). We have not had direct access to their actual "craft" (Mintzberg, 2004), their leadership in practice. Hence, their T1, the theory that can be derived from this practice, remains inaccessible to us. This circumstance restricts the scope of conclusions legitimately drawn from our study.

\section{Conceptualizations of leadership}

The distributed image of school leadership constructed from the portfolio texts (Figure 1) is corroborated by the responses to the questionnaires, summarized in tables 1-6. School leadership is conceptualized as a knowledge and value based practice exercised by role models focused on core school objectives, constructed in knowledge building interactions fusing research based theory and lessons learned from practice. These are the ideals. On the other hand, leadership is always contextual in the sense that it must be attuned to the situation it is exercised in (Bush, 2007). Consequently, the particular blend of leadership to be exercised in any situation cannot be learned without taking the workplace context into account (Rushmer, Kelly, Lough, Wilkinson, \& Davies, 2004). Our findings reflect basic elements in Nordic traditions in leadership (cp. Klemsdal, 2009; Lægreid et al., 2013; Schramm-Nielsen et al., 2004). This is evident in participant emphasis on collective and relational leadership built on openness, communication, trust, support and encouragement. We also see it in their understanding of the school leader role as underpinned by values of confidence, respect and collaboration (see figure 1).

However, these ideals may reflect surface harmonies rather than realities. Møller (2009) found tensions between notions of distributed and heroic leadership when investigating how a school leader constructed her leadership for learning in a Norwegian context. In our material there are tensions between conflicting expectations from colleagues and community, between individual needs for respectful recognition and the collective urge to move on, and between administrative demands and a focus on learning.

Initially, we sketched three theoretical approaches to school leadership, which are often presented as mutually exclusive, viz. distributed leadership, instructional leadership, and transformational leadership. Our informants have been under the influence of all three, which is reflected in their leadership ideals. Figure 1 testifies to the influence of instructional leadership, or leading for learning with a focus on student learning, classroom practices and learning communities. At the same time, they have been influenced by ideas of distributed leadership (Spillane, 2006; Gronn, 2002), emphasizing leadership as relational 
practice constructed through collective interactions. The central role of the school leader in theories of instructional leadership (Robinson, 2011; Hallinger, 2003) sometimes verge on the heroic, which may be reflected in our participants' notions of themselves as knowledgeable and value based role models. The line between knowledgeable instructional leader, interactive distributive leader and inspirational and value based transformational leader may be hard to draw. We see traces of all three in our informants' concepts of leadership.

\section{Impacts on participant leadership}

Testimonials of our participants indicate that new conceptualizations of leadership have been developed through a variety of activities and learning spaces, where theory has been fused with practical experience into the images of school leadership sketched in figure 1. Referring to Reynolds and Vince (2007), Lysø et al. (2011) observe that leadership programs seem to have gone from being very theoretically founded to becoming more operational and grounded in practice. However, Møller (2009, 2011) found that school leaders derive their understanding of themselves as professionals from collaboration with colleagues, previous work experiences, and working closely with students-not from formal leadership education. The apparent dichotomy between theory and practice implicit in these observations may have been bridged by our participants. Interpreted in a less dichotomous manner, our findings indicate that theories (T3) from the syllabus have been used in a reflective manner (T2) to pave the way for new practices in leadership (T1) (Ertsås \& Irgens, 2016).

Mintzberg (2004) associated art with seeing first, craft with doing and science with thinking first. 50 out of the 51 students who responded to the questionnaire claim that their participation in the program has caused changes in their workplaces. Furthermore, approximately two thirds of the participants maintain that exposure to relevant theory has impacted their leadership the most. We interpret this as an indication that science, understood as a broad term that includes research-based theories in the course syllabus, has informed and inspired the craft of our students.

Table 7 Effects of program related to Mintzberg's triangular theory of leadership

\begin{tabular}{|lll|}
\hline Art & Science & Craft \\
\hline Confident leadership 55\% & Knowledge development 67\% & Reflection with others 43\% \\
\hline Self insight 39\% & Theory and research 63\% & Access to leadership tools 28\% \\
\hline Leadership profile 39\% & Knowledge building 43\% \\
\hline & Instructional leadership 39\% \\
\hline
\end{tabular}

In table 7 the concepts of art, craft and science have been related to some of the program elements and learning outcomes that the students have found most useful. Art represents intuition, inspiration and passion in contrast to the factoriented rationality of science and the practicality of craft. Much of what the 
participants have been working with in the program has been "strong theory", T3. Materials have been chosen and study processes structured to facilitate a more appropriate, articulated action theory, T2. According to Ertsås and Irgens (2016), this is a necessary prerequisite to avoid developing a near-sighted practice based on assumptions derived predominantly from primary experiences.

Instructional leadership theories (Hallinger, 2003) highlight the school's core activities. In our findings we see how aspects of instructional leadership have colored our participants' conceptions of their own role as leaders and prompted them to move their leadership closer to the classroom. According to Robinson (2011), instructional leadership is the mode of school leadership that most effectively influences student learning.

Mintzberg (2009) points out that leaders often work under high pressure. Consequently, they need the confidence that comes with self-insight, knowledge of their role as leader, and the mandate that comes with it. With these elements in place, leaders often rely on what appears as intuition to make inspirational decisions, the "artistic" qualities of their leadership (Austin \& Devin, 2003, p. xxii).

In our material, the action oriented aspects of leadership are represented by Reflections with others and the Toolbox, as well as the written assignments in which the students discuss their own practices in the light of theory. Reflections with others represent processes in which participants apply theory to their own practical experiences and challenges. This is done orally in group and plenary discussions, in writing when giving fellow students feedback on portfolio text drafts and receiving such feedback. These are action-oriented procedures aimed at supporting the enhancement of the participants' action theory (T2) with strong theory (T3) in combination with practical illustrations (T1).

The Toolbox represents a working method where participants are explicitly assisted in translating strong theory (T3) into "tools", forging the link between theory and practice (cp. Lysø et al., 2011). We have seen students confirming that their toolbox has been "filled up" during the program.

All in all, we see this as indications that art, craft and science elements may work together to produce more confident, transparent and reflective school leaders with a strengthened $\mathrm{T} 2$. In their responses we see traces of insights that underpin leadership practices that support improvements in student learning according to Robinson (2011). Participant focus is directed towards classroom activities and the development of learning communities for teachers as well as students. Yet, to what extent their participation in the program has empowered them to navigate the complex and sometimes conflicting school agendas remains to be seen.

In our study, we have investigated how a cohort of 63 school leaders conceptualize school leadership and the impact of participation in the program. We claim to have established connections between a development of participants' pronounced action theory (T2) through a program combining strong theory (T3) 
and experience-based learning. The connection between their action theory (T2) and the theory they actually practice (T1), has not been investigated in our study, and is an obvious field for future research. Incidentally, the assumption that there are inherent, causal links from T3 to T2, and from T2 to T1 lies at the heart of what we do at universities.

\section{References}

Argyris, C., \& Schön, D. (1978). Organizational learning: A theory of action perspective. Reading, MA: Addison-Wesley.

Austin, R. D., \& Devin, L. (2003). Artful making: What managers need to know about how artists work. Upper Saddle River, NJ: Prentice Hall.

Bass, B. M. (1999). Two decades of research and development in transformational leadership. European Journal of Work and Organizational Psychology, 8(1), 9-32.

Bowen, G. A. (2006). Grounded theory and sensitizing concepts. International Journal of Qualitative Methods, 5(3), Article 2. Retrieved from http://www.ualberta.ca/ iiqm/backissues/5_3/pdf/bowen.pdf

Bush, T. (2007). Educational leadership and management: Theory, policy, and practice. South African Journal of Education, 27(3), 391-406.

Bush, T., \& Glover, D. (2003). School leadership: Concepts and evidence. Reading: National College for School Leadership.

Corbin, J., \& Strauss, A. (2008). Basics of Qualitative Research. 3e. Los Angeles: Sage.

Czarniawska, B. (2003). Forbidden knowledge. Organization Theory in Times of Transition. Management Learning, 34(3), 353-365.

Easterby-Smith, M., Thorp, R., \& Lowe, A. (1991). Management Research. An Introduction. London: Sage.

Ertsås, T. I., \& Irgens, E. J. (2016). Professional theorizing. Teachers and Teaching. Theory and practice. doi: http://dx.doi.org/10.1080/13540602.2016.1205013

Ghoshal, S. (2005). Bad management theories are destroying good management practices. Academy of management, learning \& education, 4(1), 75-91.

Gronn, P. (2002). Distributed leadership as a unit of analysis. The Leadership Quarterly, 13(4), 423-451.

Hallinger, P. (2003). Leading educational change: Reflections on the practice of instructional and transformational leadership. Cambridge Journal of Education, 33(3), 329-352.

Hofstede, G. (1993). Cultural constraints in management theories. Academy of Management Executive, 7(1), 82-94.

Huber, S. G. (2004). School leadership and leadership development: Adjusting leadership theories and development programs to values and the core purpose of school. Journal of Educational Administration, 42(6), 669-684.

Irgens, E. J. (2016). Skolen. Organisasjon og ledelse, kunnskap og leering. [The School. Organization and leadership, knowledge and learning.] Bergen: Fagbokforlaget.

Irgens, E. J., \& Ness, H. (2007). Exporting Knowledge and Values: A Discussion of Managerial Challenges when Attempting to Diffuse CSR across Company and National Borders. In F. den Hond, F. G. A. de Bakker, \& P. Neergaard (Eds.), Managing Corporate Social Responsibility in Action: Talking, Doing and Measuring (pp. 127-145). London: Ashgate Publishing Group.

Klemsdal, L. (2009). Den nordiske modellen i tre deler [The Nordic model in three parts]. Sosiologi i dag, 39(1), 3-10. 
Kvernbekk, T. (2005). Pedagogisk teoridannelse. Insidere, teoriformer og praksis.

[Pedagogical theory formation. Insiders, theory forms and practice.] Bergen:

Fagbokforlaget.

Lumby, J., Walker, A., Bryant, M., Bush, T., \& Björk, L. (2009). Research on Leadership Preparation in a Global Context. In M. D. Young, G. Crow, J. Murphy, \& R. Ogawa (Eds.), The Handbook of Research on the Education of School Leaders. London: Routledge.

Lysø, I. H., Stensaker, B., Aamodt, P. O., \& Mjøen, K. (2011). Led to leadership, report 1 from the evaluation of the National Leadership Education for School Principals. Oslo: NIFU/NTNU Samfunnsforskning.

Lægreid, P., Nordø Å. D., \& Rykkja, L. H. (2013). Public Sector Reform in Norway: Views and Experiences from Senior Executives. Country Report as part of the COCOPS Research Project.

St.meld. nr. 31 (2007-2008). Kvalitet i skolen. [Government White Paper no 31 (2007-2008). Quality in Schools]. Retrieved from https://www.regjeringen.no/contentassets/806ed8f81bef4e03bccd67d16af76979/no/pdfs/s $\underline{\text { tm200720080031000dddpdfs.pdf }}$

Mintzberg, H. (2004). Managers Not MBAs: A hard look at the soft practice of managing and management Development. San Francisco: Berrett-Koehler Publishers.

Mintzberg, H. (2009). Managing. Harlow, England: Prentice Hall.

Mordal, S. (2014). Ledelse i barnehage og skole. En kunnskapsoversikt. [Leadership in kindergarten and school. An overview.] Trondheim: SINTEF Teknologi og samfunn.

Møller, J. (2009). Learning to share: a vision of leadership practice. International Journal of Leadership in Education, 12(3), 253-267. doi: http://dx.doi.org/10.1080/13603120802684530

Møller, J. (2011). Rektorers profesjonsforståelse - faglig autonomi og administrativ underordning. [Head teachers' understanding of their profession - professional autonomy and administrative subordination]. In J. Møller \& E. Ottesen (Eds.). Rektor som leder og sjef. Om styring, ledelse og kunnskapsutvikling i skolen (pp. 27-50). [The head teacher as leader and boss. On administration, leadership and knowledge development in schools]. Oslo: Universitetsforlaget.

Reynolds, M., \& Vince, R. (Eds.) (2007). The Handbook of Experiential Learning and Management Education. Oxford: Oxford University Press.

Robinson, V. (2011). Student-Centred Leadership. San Francisco: Jossey-Bass.

Rushmer, R., Kelly, D., Lough, M., Wilkinson, J. E., \& Davies, H. T. (2004). Introducing the Learning Practice-III. Leadership, empowerment, protected time and reflective practice as core contextual conditions. Journal of evaluation in clinical practice, 10(3), 399-405.

Schramm-Nielsen, J., Lawrence, P., \& Sivesind, K. H. (2004). Management in Scandinavia. Culture, context and change. Cheltenham: Edward Elgar.

Spillane, J. (2006). Distributed Leadership. San Francisco: Jossey-Bass.

Weniger, E. (1953). Theorie und Praxis in der Erziehung. In E. Weniger (Ed.), Die

Eigenständigkeit der Erziehung in Theorie und Praxis (pp.7-22). Weinheim: Beltz. 